\title{
Analysis of Subsidy and Reinvestment Programme (SURE-P) and Youth Empowerment in Nigeria 2012-2014
}

\author{
${ }^{1}$ Dr. Okwudili Chukwuma Nwosu, ${ }^{2}$ Emmanuel Ugwuerua, \\ Provost, the College of Education, Nsukka, Enugu State, Nigeria \\ Director, the College of Education, Nsukka, Enugu State, Nigeria
}

\begin{abstract}
Subsidy Reinvestment and Empowerment Programme (SURE-P), was inaugurated on $13^{\text {lh }}$ February, 2012, the aim was to plough black the savings from the reduction of subsidies on petroleum products into programmes that will empower Nigerian youths. This article examines the extent to which Subsidy and Reinvestment Programme SURE-P has empowered Nigerian youths between 2012 and 2014. The article notes that there is a considerable relationship between Subsidy Reinvestment and Empowerment Programme (SURE$P)$ and youth empowerment in Nigeria. The article contends that SURE-P established graduate internship scheme of the community services, women and youth employment programme under the social safety net component; Sure-P Technical Vocational Education and Training (TVET) Programme; Mass Transit Programme and Maternal and Child Health $(\mathrm{MCH})$ Programme all geared towards youth empowerment. Finally, the article concludes that the current mode of operation of SURE-P still needs to be changed by adopting concrete strategies of youth empowerment, and most importantly creating enabling environment for foreign investors to come in, who can provide opportunities of employment for Nigerian youths.
\end{abstract}

Keywords: Empowerment, Fuel Subsidy, Subsidy, SURE-P, Youth Empowerment

\section{Introduction}

Nigeria economy solely depends and revolves around the oil industry. This dependency on oil is not in the best interest of the country, assuming the oil dries up, the Nigerian economy will definitely collapse.[1] Nigeria is the world's 14th largest producer of crude oil.[2] It possesses the world's 8th largest proven natural gas reserves. The country had 4 refineries with an installed production capacity of 445,000 barrels of fuel per day, adequate to meet its domestic needs with a surplus for export. Nigerian oil fields are situated in the Niger Delta area of the country.

The Niger Delta area is viewed as the third, largest wetland in the world, whose flora and fauna has sustained life for generations.[3] For decades running, its oil wealth has provided the bulk of Nigeria's wealth. In the 1970's, era of oil boom, oil gave Nigeria a significant economic power and diplomatic leverage.[4] In spite of having fabulous economic potentials, and a territory blessed with natural resources, Nigeria has not fared so well, economically. Yet the country is a large net importer of gasoline and other petroleum products, the youths are the worst hit and unemployment rate is always on the increase. Inflation runs at roughly $10 \%$ per annum.[5] Over the years, it is observed that the socio-economic prospects of the Nigerian citizens have dwindled and youth empowerment is at its lowest ebb, even as the earnings and income generated from oil continued to sky-rocket. [6]

The greatest challenge facing the country today is absence of youth empowerment, our youths are not empowered. Youths after graduation roam the streets of Nigeria in search of work, unemployment has maintained a rising trend over the years. Over 50 percent of the Nigerian youth population is unemployed. A recent survey puts the figure at 54 percent. This figure was reduced by about 16 people on $15^{\text {th }}$ March 2014 , not as a result of job provision, but by the claws of death at the Nigerian Immigration Service recruitment exercise.[7] The number of applicants were not fewer than seven hundred thousand with about four thousand positions. [8] Every year, over 300,000 graduates are churned out from the tertiary institutions nationwide. [9] This number grows yearly and translates into more and more youths wandering the streets of Nigerian cities. There is no doubt that youth's unemployment is a societal problem in any nation, but the Nigerian situation is something else. This most times account for most of the social crimes perpetrated by graduates in Nigerian society today. If the youths are empowered and have something to do, the level of prostitution, armed robbery, oil bunkering, internet frauds, drug addiction, trafficking, rape, kidnapping and all facets of violence like the militant in the Niger Delta and Boko Haram in the North East will be reduced to the barest minimum.

It is instructive that successive administrations in Nigeria have focused on the removal of fuel subsidy and increase in the price of fuel as a means of raising additional revenue for development efforts. Before every fuel price increase, the government promises life in abundance for all citizens and goes ahead to tabulate projects and programmes where the savings will be invested. The administration of Sani Abacha went as far as 
setting up the defunct Petroleum Trust Fund which invested the saved funds in specific and identifiable projects. However, the more the increase in the price of fuel, the more Nigerians continue to witness poor governmental service delivery, increase in unemployment rate and public infrastructure continues to decay. This development fuels another round of steps and advocacy by government for further reductions to, or removal of what has become a doubtful subsidy. Moreover, successive Nigerian governments have been unable to use the oil wealth to empower the youths.[10] This has been categorized as one of the serious impediments to social progress. Apart from representing a colossal waste of a country's manpower resources, it generates welfare loss in terms of lower output, thereby leading to lower income and well-being. [11] SURE-P was targeted to ensure that the Federal Government's part of the savings from fuel subsidy removal or reduction is applied to critical mitigate the spate of youth unemployment in the country through the re-investment of the subsidy funds. However, the problem now lies on the possibility of SURE-P empowering the youths by the fuel subsidy removal.

Based on the issues highlighted above, the purpose of this study is to analyze the relationship between Subsidy Reinvestment and Empowerment Programme (SURE-P) and creation of employment for the Nigerian youths between 2012 and 2014.

\subsection{Fuel Subsidy In Nigeria}

\section{Content}

A subsidy is an economic benefit or financial aid provided by a government to support a desirable activity, so as to keep prices low, maintain the income of the producers of critical or strategic products, maintain employment levels, or induce investment to reduce unemployment. [12] It can tentatively be defined as any government program that potentially permits the firm to increase its profits beyond what they would have been in the absence of the government program. A subsidy can also be referred to as an assistant to a business or economic sector or producers. [13] The major aim of all subsidies is to reduce the market price of an item below its cost of production. Most subsidies are put in place by the government for producers or are distributed as subventions in an industry to prevent the decline of that industry (e.g.. as a result of continuous unprofitable operations) or an increase in the prices of its products or simply to encourage it to hire more labour (as in the case of a wage subsidy). Examples are subsidies to encourage the sale of exports; subsidies on some foods to keep down the cost of living, especially in urban areas; and subsidies to encourage the expansion of farm production and achieve self-reliance in food production.

A subsidy is a reverse tax. It is a deliberate attempt by government to support a chosen economic agent -a consumer and a provider and it can be applied in any market that involves the buying and selling of products and or services. [14] It is basically a government action that decreases the consumption price of the consumer and (or) increases the selling price of the producer.

Fuel subsidy is a taxpayer-funded payment made to encourage development/distribution of alternative fuels/energy as well as for the exploration and development of more traditional energy sources. A fossil fuel subsidy is also any government action that lowers the cost of fossil fuel energy production, raises the price received by energy producers or lowers the price paid by energy consumers. [15] However, the application of or the use of subsidies is not exclusive to developing economies. Subsidies span different types of economic activities, the most featured in popular press tend to be agricultural and energy related subsidies. The subsidy could be direct in the form of price controls, tax exemptions or the provision of grants; this more or less entails the injection of cash back into the hands of either the consumer or the producer. The indirect form of subsidy is more in the form of the provision of industrial input requirements in the form of favourable regulator, frameworks, research and development. Different types of subsidies include the following: Grants and other direct payments; Tax concessions; In-kind subsidies; Cross subsidies; Credit subsidies and government guarantees and Hybrid subsidies.[16] The history of fuel subsidy removal in Nigeria is rather a long one particularly with the negative effects it has on the polity. Specifically, the story of subsidy removal dates back to 1978, when, the then military government of Gen. Olusegun Obasanjo reviewed upward the pump price of fuel which was at 8.4 kobo to 15.37 kobo. From this period, it had been from one subsidy removal to the other. [17]

The TABLE below provides a clearer picture of the different pump prices by the different administrations from 1978 to Jan. 2012.

Data on Petroleum Price Increases/Adjustments in Nigeria (1978-2012).

\begin{tabular}{|lllcr|}
\hline S/N & DATE & ADMINISTRATION & PRICE & $\%$ CHANGE \\
\hline 1 & 1978 & Gen. Olusegun Obasanjo (as military ruler) & $15.37 \mathrm{k}$ & - \\
2 & 1982 & Alh. Shehu Shagari & $20 \mathrm{k}$ & - \\
3 & 1990 & Gen. Ibrahim Babangida & $60 \mathrm{k}$ & $300 \%$ \\
4 & 1992 & Gen. Ibrahim Babangida & $70 \mathrm{k}$ & $17 \%$ \\
5 & 1992 & Gen. Ibrahim Babangida & N3.25k & $364 \%$ \\
6 & 1993 & Gen. Ibrahim Babangida & N5.00 & $54 \%$ \\
7 & 1994 & Chief Ernest Shonekan & N11.00 & $120 \%$ \\
8 & $1994 / 98$ & Gen. Sani Abacha & N11.00 & - \\
\hline
\end{tabular}


Analysis of Subsidy and Reinvestment Programme (SURE-P) and Youth Empowerment in ...

\begin{tabular}{|llllr|}
\hline 9 & 2000 & Olusegun Obasanjo (as civilian ruler) & N20.00 & $82 \%$ \\
10 & 2000 & Olusegun Obasanjo (as civilian ruler) & N22.00 & $10 \%$ \\
11 & 2001 & Olusegun Obasanjo (as civilian ruler) & N26.00 & $18 \%$ \\
12 & 2003 & Olusegun Obasanjo (as civilian ruler) & N40.00 & $54 \%$ \\
13 & 2004 & Olusegun Obasanjo (as civilian ruler) & N45.00 & $13 \%$ \\
14 & 2007 & Olusegun Obasanjo (as civilian ruler) & N70.00 & $56 \%$ \\
15 & 2007 & Alh. Umaru Shehu Yardua & N65.00 & $0.07 \%$ \\
16 & 2012 & Dr. Goodluck Jonathan & N97.00 & $73 \%$ \\
& & & & \\
\hline
\end{tabular}

Source: Ering \& Akpan (2012)

\subsection{Empowerment}

Empowerment has no clear definition.[18] Most people narrowly use the term, the concept is not defined by some others at all. Thus, many see the concept as nothing more than the most recently popular buzz word to be thrown in to make sure old programs get new funding. However, empowerment is much more than that. [19] Empowerment is a process that challenges our assumptions about the way things are and can be. It challenges our basic assumptions about power, helping, achieving, and succeeding. To begin to demystify the concept of empowerment, we need to understand the concept broadly in order to be clear about how and why we narrow our focus of empowerment for specific programs and projects and to allow discussion of empowerment across disciplinary and practice lines.

At the core of the concept of empowerment is the idea of power. [20] The possibility of empowerment depends on two things. First, empowerment requires that power can change. If power cannot change, if it is inherent in positions or people, then empowerment is not possible, nor is empowerment conceivable in any meaningful way. In other words, if power can change, then empowerment is possible. Second, the concept of empowerment depends upon the idea that power can expand. This second point reflects our common experiences of power rather than how we think about power. To clarify these points, we first discuss what we mean by power. Power is often related to our ability to make others do what we want, regardless of their own wishes or interests. [21] Traditional social science emphasizes power as influence and control, often treating power as a commodity or structure divorced from human action. [22] Conceived in this way, power can be viewed as unchanging or unchangeable. Power exists within the context of a relationship between people or things. [23] Power does not exist in isolation nor is it inherent in individuals. By implication, since power is created in relationships, power and power relationships can change. Empowerment as a process of change, then, becomes a meaningful concept.

Empowerment is a construct shared by many disciplines and arenas: community development, psychology, education, economics, and studies of social movements and organizations, among others. How empowerment is understood varies among these perspectives. In recent empowerment literature, the meaning of the term empowerment is often assumed rather than explained or defined. It is easy to define empowerment by its absence but difficult to define in action as it takes on different forms in different people and contexts. [24] Even defining the concept is subject to debate. Asserting a single definition of empowerment may contradict the concept of empowerment. [25] A common understanding of empowerment is necessary, however, to allow us to know empowerment when we see it in people with whom we are working, and for program evaluation. How we precisely define empowerment within our projects and programs will depend upon the specific people and context involved. As a general definition, however, we suggest that empowerment is a multi-dimensional social process that helps people gain control over their own lives. [26] It is a process that fosters power in people, for use in their own lives, their communities, and in their society, by acting on issues that they define as important. We suggest that three components of our definition are basic to any understanding of empowerment. Empowerment is multi-dimensional, social, and a process. It is multi-dimensional in that it occurs within sociological, psychological, economic, and other dimensions. Empowerment also occurs at various levels, such as individual, group, and community. Empowerment, by definition, is a social process, since it occurs in relationship to others. Empowerment is a process that is similar to a path or journey, one that develops as we work through it. Other aspects of empowerment may vary according to the specific context and people involved, but these remain constant. In addition, one important implication of this definition of empowerment is that the individual and community are basically involved.

\subsection{Youth Empowerment}

A youth is any individual within the age of eighteen and thirty five years irrespective of gender. [27] It is good to be a youth but youth empowerment is better. Empowerment can be seen as the means of assisting, helping or encouraging people. Youth empowerment in a nutshell is the means through which the youths of any country are assisted to succeed in life. It is shameful that when youth empowerment is mentioned, people think that it is only the function of the government to empower the youths. This is not so, you as an individual, can empower the people around you. Youth Empowerment is defined as an attitudinal, structural, and cultural 
process whereby young people gain the ability and authority to make decisions and implement change in their own lives and the lives of others. [28] Generally, some people understand youth empowerment as the means through which the youth are encouraged financially or skillfully. The word, empowerment, is used on everyday life of people. Youth empowerment is beyond these two, it involves a lot more ranging from all those activities that will transform the youth into a better individual.

Youth empowerment is the outcome by which youth, as change agents, gain the skills to impact their own lives and lives of other individuals, organizations and communities. [29] The definition of youth is dependent of any particular nation as some have the definition as lady or young man between the age of 18 and forty. Youth empowerment can be viewed from both individual and organizational level, at the individual level it is exercising power over ones' life by being skilled, critically aware, and active in creating community change. At the organizational level is the implementation of a culture, vision, and system that supports youth empowerment at the individual level. [30] Continuing, youth empowerment can be seen as having a threepronged approach that effectively engages young people in work that challenges them to develop skills, gain critical awareness, and participate in opportunities that are necessary for creating community change:

- Skill Development: The process of strengthening the skills of youth so that they know how to effectively make decisions, positively interact with their peers, and act as community advocates.

- Critical Awareness: The process of providing youth with the information and resources necessary for analyzing issues that affect their lives and environments as well as strategize on ways to act as change agents in their communities.

- Opportunities: The process of providing youth with platforms for decision-making and encouraging their active participation in creating community change. [31]

Youth empowerment is of good importance to both nations and the empowered. With youth empowerment, the future prosperity of nations is secured because these are the people that are, and will take care of many offices and functions in the country. There are youths who are running many managerial functions in many institutes. There are also those who are going to manage top offices in the future in accordance with the popular statement "the youths are the leaders of tomorrow".

Statistically Nigeria has a youth population of about 67 million, aged between 15 and 35 years. 42.2\% of these young people don't have a means of livelihood while only $20 \%$ have more than the secondary school certificate. These figures reveal that majority of the youths in our country find it hard to make ends meet calling for the need for effective youth empowerment programmes and strategies in the country.

Youth empowerment can be highlighted under the following classifications: Financial youth empowerment; Academic/ Educational Youth Empowerment; Moral Youth Empowerment; Agricultural Youth Empowerment; Skills Acquisition Youth Empowerment. [32] No nation can do without empowering their youths. [33] This is so because the youths of today are elders of tomorrow. All should empower the youths. The importance of youth empowerment is outlined thus: Poverty eradication; Good education standard; Good governance; Crime reduction; National Growth; Security and Technological Development. [34]

\subsection{SURE- $P$ And Employment Generation}

On the 13th of February 2012, President Jonathan of Nigeria inaugurated the SURE-P Committee whose mandate was to 'deliver service with integrity' and 'restore people's confidence in the government'.[35] The Committee expressed its desire to ensure that the objectives of the programme will be achieved.

At the establishment of SURE-P, the Federal Government called for support from the private sector to enable it to address the unemployment situation in the country. [36] The Project Director, Graduate Internship Programme of Subsidy Re-investment and Empowerment Programme, Mr. Peter Papka, made the call during an orientation and induction programme for interns. The GIS was inaugurated in October, 2012 to create an opportunity for graduates to be attached to firms where they could work for a year and enjoy a monthly stipend of N18,000. Such interns can use the opportunity to gain experience and enhance their employability. Papka said since the commencement of the programme last year, there had been over 83,000 beneficiaries. This, he noted, was beyond the threshold of 50,000 allotted for the scheme in any given year. Its objectives are to enhance the employability of up to 50, 000 graduates through internship programmes; reduce the vulnerability of unemployed graduates and build manpower base towards attaining national development operations. The GIS programme would cost the nation N900m monthly.

The N900m figure is based on the N18, 000 monthly stipend expected to be paid to about 50, 000 graduates that will benefit from the scheme in the 2013 fiscal year. [37] Speaking during an interactive session with chief executive officers of companies in the private sector, the Minister of Finance, Dr. Ngozi OkonjoIweala, stated that the programme was part of the government's tripod strategy towards addressing youth unemployment in Nigeria. The tripod strategy, Okonjo-Iweala noted, was anchored on the realisation that the government acknowledged the fact that it could not solve the unemployment problems alone. She stated: 
The GIS is part of our tripod strategy for responding to the youth unemployment in Nigeria. This strategy has three layers because we recognise that the challenge is a multi-dimensional one. This tripod strategy is anchored on the realisation that we acknowledge the fact that government alone cannot solve the problem of unemployment in Nigeria. The key to solving unemployment lies with the private sector. This is why a major policy priority is the creation of an enabling environment for businesses to thrive and employ people. [38]

Also speaking at the event, the Chairman, SURE-P, Dr. Christopher Kolade, said the programme commenced in October 2012 as a social safety net to provide short term employment for graduates. [39] He called for support for the programme from the private sector, adding that the buy-in from the firms had not been commensurate with the rate of graduate registration. He stated:

The GIS will help us to have a new understanding of what SURE-P is all about because we are using this to reduce unemployment in the country through youth empowerment. We are looking at our graduates as seeds materials for the future and that is why we are making this investment in them to help them to develop their intellectual capacity to rebuild a strong nation. [40]

Mr Audu Maikori, the SURE-P Convener, Community Service, Women and Youth Employment, told the News Agency of Nigeria (NAN) that the Graduate Internship Scheme (GIS) was however targeted to create opportunity for 25,000 graduates, who would be attached to 7,000 firms across the country. The SURE-P official said the beneficiaries would be mentored by the firms to enhance their employment opportunities. [41]

\section{Result And Discussion}

The SUIRE-P Committee in carrying out the mandate trusted upon it by the President, to mitigate the spate of youth unemployment in the country, made some efforts which include:

\subsection{Establishment Of Graduate Internship Scheme Of The Community Services, Women And Youth Employment Programme Under The Social Safety Net Component.}

In line with Mr. President's promise to mitigate the spate of youth unemployment in the country through the re-investment of the subsidy funds, the Federal Government initiated the graduate Internship Scheme under the Social Safety Net Component of Subsidy Reinvestment and Empowerment Programme (SURE-P). The ultimate goal is to reduce unemployment among graduates and stimulate economic growth, as part of priority transformation agenda of the current administration, while also enhancing opportunities towards the attainment of Vision 2020.

The scheme has the objective to create opportunities for unemployed graduates to be engaged for a period of one (1) year in reputable firms and institutions, to enable them acquire skills and experience and enhance their employability. The scheme would be a form of partnership with firms and institutions in which they get free labour and undertake to groom and mentor the interns to acquire skills on the job experience while government pays stipends to the interns. This will help equip graduates towards meeting the demands of employers in the current labour market. Interns would be deployed to firms and institutions in their areas of residence for convenience. Interns would be deployed according to the relevance of their discipline to the firms. This will not only improve manpower development but will also broaden the applicant's expertise. And these interns would be under close supervision for the period, to ensure diligence. The Graduate Internship Scheme (GIS) was meant to employ 50,000 youth across the country, to ensure that their skills have been developed towards empowering them to be employable in the short/medium/long term. GIS will ensure that youths are attached as apprentices in reputable public/private firms for a period of one year where the skills of such individuals will be sharpened.[42]

In view of the above, the Graduate Internship Scheme (GIS) is established as part of the Subsidy Reinvestment and Empowerment Programme (SURE - P) and it will employ 50,000 youth across the country to ensure that their skills have been developed towards empowering them to be employable in the short/medium/long term. GIS will ensure that youths are attached as apprentices in reputable public/private firms for a period of one year where the skills of such individuals will be sharpened as well as boost their chances of becoming self-employed. While the GIS is designed as a short-term measure, it has high prospects for job creation. The specific objectives of the program are; "To enhance the employability of up to 50,000 unemployed graduates in the 36 states of the Federation and the FCT through internship programs in preselected institutions; and to reduce the vulnerability of unemployed graduates and to build manpower base towards attaining national development operations. During this period the Federal Government of Nigeria will be responsible for paying a monthly stipend to the graduate interns. The participating institution will be expected to provide adequate opportunities for training and mentoring the interns". [43]

Community Service, Women and Youth Employment Programme; One of the aims of Community Service, Women and Youth Employment (CSWYE) Programme is to tackle the problem of youth unemployment by creating temporary employment for 10,000 youths in each state of the Federation and Federal 
Capital Territory. Of these, at least $30 \%$ must be women and the jobs are designed to be created in labour intensive community development services. The women and youth beneficiaries of the CSWYE programme were trained in some basic skills and supplied with working tools and equipment as appropriate. They also receive payment based on work done. The states where the implementation of Graduate Internship Scheme (GIS) had taken effect fully, in all the Local Government Areas, are Enugu, Yobe, Ekiti, Lagos, Benue and Oyo. [44]

\subsection{Subsidy Reinvestment And Empowerment Programme (Sure-P) Technical Vocational Education And Training (TVET) Programme}

In line with Mr. President's promise to encourage wealth creation and mitigate the scourge of youth unemployment in the country, the Federal Government through the Subsidy Reinvestment and Empowerment Programme (SURE-P) has developed a Technical, Vocational Education and Training (TVET) programme to be managed by a Project Implementation Unit (PIU) in the Ministry of Labour and Productivity. The (PIU) will manage the implementation of the TVET program which has the mandate to invest in the development of vocational and technical education in Nigeria. This scheme is expected to stimulate the economic growth needed as part of the transformation agenda of the current administration while also enhancing opportunities towards the attainment of Vision 20: 2020. [45] The scheme has the mandate to equip young Nigerians with skills in three broad areas: vocational/technical skills, life skills and entrepreneurship. It is targeted at bridging the demand gaps in some industry areas: ICT/Telecoms, Creative (e.g. movies, music, fashion, etc) others are Hospitality and Tourism, Agrobusiness, Mass Housing/Construction, Artisans, Marine, Oil and Gas and Mechanical Fabrication/Woodwork.

\subsection{Mass Transit}

Under the mass transit programme SURE P is collaborating with stake holders in the transport industry by applying parts of its funds to support a revolving loan scheme, for road transport operators across the country. The loan scheme managed by an Infrastructure Bank, helps to reduce the cost of transport to citizens, to cushion the effects of partial fuel subsidy removal. In the year 2012, SURE-P disbursed N8.9 billion for the mass transit programme purposes, out of which 18 registered transport companies nationwide have drawn from, to purchase 809 buses for use of Nigerians.

\subsection{Maternal and Child Health (MCH) Programme}

Total number of health care workforce recruited as at July 2013, stood at 6,630. [46] They were deployed to provide quality antenatal, skilled birth delivery at birth and post-natal services for previously underserved rural, poor women accessing maternal, neonatal and child health services in 500 SURE-P supported primary health care (PHC) centres spread across the 36 states and FCT. These health care workers comprised: 1,304 midwives; ,254 community health extension workers (CHEWs); and 3,072 female village health workers (VHWs) cut across the six geo-political zones of the country.

\subsubsection{Monitoring And Evaluation/Performance Management}

The health workers are now providing quality antenatal, skilled birth delivery and postnatal services to pregnant women and their babies across the SURE-P MCH Programme, has generated significant increase in the uptake of services at primary health care centres in communities hosting them. 223,786 pregnant women have received antenatal care services in SURE-P MCH supported facilities, 28,435 deliveries have been taken by skilled birth attendants in these same facilities, 19,514 new acceptors of family planning have been recorded in these same facilities

\subsubsection{Conditional Cash Transfer (CCT)}

SURE-P, have successfully launched the Conditional Cash Transfer (CCT) Pilot Programme in DeiDei Comprehensive Health Centre, Bwari Area Council, Abuja, Federal Capital Territory. In 5 primary health care (PHC) centres in FCT, a total of 2,150 beneficiaries have been enrolled into the programme as at $30^{\text {th }}$ June, 2013 as follows:

- Dei-Dei Comprehensive Health Centre: 670 beneficiaries

- Old Dei-Dei Health Post: 200 beneficiaries

- Byazhin Health Centre: 272 beneficiaries

- Dutse Alhaji Health Centre: 449 beneficiaries

- Kuje Health Centre: 559 beneficiaries

Inauguration of State CCT Steering Committees has occurred in the Federal Capital Territory (FCT) and 8 pilot states namely: Anambra, Bauchi, Bayelsa, Ebonyi, Kaduna, Niger, Ogun and Zamfara States. 
Capacity building of PHC facility staff and Ward Development Committee (WDC) members has been completed in 32 pilot PHC facilities in the 8 other pilot states, Beneficiaries are now being enrolled in the pilot PHC facilities in the 8 other pilot states. [47]

\section{Conclusion}

This study was aimed at ascertaining the role of SURE-P in empowering Nigerian youths. It also tried to ascertain whether there was a considerable relationship between SURE-P and creation of employment for Nigeria youths; Our findings apparently signified that SURE-P took some giant strides in fighting the scourge of unemployment among Nigerian youths through some youth empowerment programmes within the period under review. However, SURE-P still needs to go further in its approaches towards creating employment by going beyond the internship scheme to creating enabling environment for investments through the provision of basic amenities like good roads, provision of power, maintaining law and order, and adequate security. This will attract investments that will give Nigerian youths lasting and better employment opportunities than providing ten thousand naira to a graduate after an internship scheme.

However, it is pertinent to point out at this juncture that there are some salient issues that were left out or not adequately discussed in this study. It is therefore suggested that future researches should be tailored to fill the gap created by such inadequacies.

\section{References}

[1]. I. Okonta, \& D. Oronto, Where vultures feast: 40 years of shell in the Niger delta (Ibadan. Kraft Books Ltd. 2001).

[2]. S.A Khan, Nigeria: The political economy of oil (London, Oxford University Press, 1994).

[3]. S.Azaiki, Inequalities in Nigeria politics ( Yenegoa, Treasure Communication Resources Ltd, 2003).

[4]. M.A. Feyide, Oil in world politics (New Haven, Connecticut, Yale University Press, 1986).

[5]. B. Onyeizugbe \& C. Onwuka, The oil and National question (Ibadan, Ibadan University Press, 2012)

[6]. N. Iluyomade, Youth empowerment in Nigeria (http://www.nwaigwe.blog.org 2011).

[7]. C.N. Okon Empowering the youths in Nigeria's depressed economy (Port Harcourt, University of Port Harcourt Press, 2014).

[8]. C.N. Okon Empowering the youths in Nigeria's depressed economy (Port Harcourt, University of Port Harcourt Press, 2014).

[9]. P. Osalor, Youth restiveness and unemployment in Nigeria: The way out (3) (http://www.onlinenigeria.com ( 2012).

[10]. T. Banki Empowering Nigerian youths; Understand all the different types, especially the main ones (http://www.about.com/lr/empowerment 2012).

[11]. M.I. Raheem, Nigeria for Africa, a case for labour export. in T. A. Oyejide and M., I., Obadan (Eds.), Applied economics and economic policy -in honour of Emmanuel C. Edozien (Ibadan: Ibadan University Press 1993).

[12]. W. E. Schrank, \& W. R. Keithly, Thalassorama, the concept of subsidies. Marine Resource Economics, //, 1999, $151-164$.

[13]. M. P. Todaro, \& S. C. Smith, Economic development (10th ed,) (Wesley, Adisson 2009).

[14]. UNEP, Energy subsidies: lessons learned in assessing their impact and designing policy reforms (Geneva, UNEP 2003).

[15]. Centre for Public Policy Alternatives, Nigeria, fuel subsidy, a desktop study (DFID, Adam Smith international, 2012).

[16]. Global Subsidies Initiative, Subsidy type,. Geneva, International environment house, National Bureau of Statistics (2010). Labour Force Survey March, 2009 ( Nigeria, NBS, 2013).

[17]. S. 0. Ering, \& F.U. Akpan, The politics of fuel subsidy, populist resistance and its socio-cconomic implications for Nigeria, Global Journal of Humanity and Social Science 12 (7), 2012, 1-9.

[18]. A. Bookman, \& S. Morgen, (Eds.), Women and the politics of empowerment (Philadelphia, Temple University Press, 1984).

[19]. D. Bailey, Using participatory research in community consortia development and evaluation, lessons from the beginning of a story". American Sociologist, 23 (4), 1992, 71-82.

[20]. D. Bailey, Using participatory research in community consortia development and evaluation, lessons from the beginning of a st ory". American Sociologist, 23 (4), 1992, 71-82.

[21]. M. Weber, The theory of social and economic organization (NewYork, Oxford University Press, 1947).

[22]. H. Lips, Women, men and power (Mountain View, CA, Mayfeld, 1991).

[23]. M. Weber, The theory of social and economic organization (NewYork, Oxford University Press, 1947).

[24]. J. Rapport, Studies in empowerment: Introduction to the issue. Prevention in Human Services, 3, 1984, 1-7.

[25]. M.A. Zimmerman, Taking aim on empowerment research, on the distinction between individual and psychological conceptions, American Journal of Community Psychology, 18(1), 1984, 169-177.

[26]. D.Bailey, Using participatory research in community consortia development and evaluation, lessons from the beginning of a story, American Sociologist, 23 (4), 1992, 71-82.

[27]. M.N. Okoye, Youth development and empowerment programmes in Nigeria: Workshop, Workshop on Youth Development, Port Harcourt 2012, 20- 25.

[28]. T.C. Kpalev, Reducing unemployment through the establishment of small scale business enterprises: m.sc. thesis University of Nigeria, Nsukka, 2013.

[29]. B.O. Obi, Poverty and youth empowerment in Nigeria: Workshop, Workshop on Youth Development, Port Harcourt 2012, 8-12.

[30]. C.J Abadua, Empowering the Niger Delta Youths: Workshop, Workshop on Youth Development, Port Harcourt $2012,1-5$.

[31]. C.J Abadua, Empowering the Niger Delta Youths: Workshop, Workshop on Youth Development, Port Harcourt 2012 , 1-5.

[32]. C.J Abadua, Empowering the Niger Delta Youths: Workshop, Workshop on Youth Development, Port Harcourt $2012,1-5$.

[33]. A. Njoku, \& A. I. Okezie, Unemployment and Nigerian economic growth (1985-2009). Proceedings from IATEL International Conference on Teaching, Learning and Change, Nigeria, 2011,

[34]. T.C. Kpalev, Reducing unemployment through the establishment of small scale business enterprises: m.sc. thesis University of Nigeria, Nsukka, 2013.

[35]. www.sure-p.com.org, (Official Website of SURE P,2012).

[36]. www.sure-p.com.org (Official Website of SURE P, 2012).

[37]. www.sure-p.com.org, (Official Website of SURE P, 2012). 
[38]. www.sure-p.com.org, (Official Website of SURE P, 2012).

[39]. www.sure-p.com.org (Official Website of SURE P, 2012).

[40]. www.sure-p.com.org (Official Website of SURE P, 2012).

[41]. www.sure-p.com.org (Official Website of SURE P, 2012).

[42]. SURE-P, Status brief on community services, women and youth employment, Nigeria: SURE-P Annual Reports, 2013.

[43]. SURE-P, Subsidy reinvestment and empowerment programme, 2012 annual reports. Nigeria: SURE-P Annual Report, 2013.

[44]. www.allafrica.com.

[45]. Sure-P Technical vocational education training programme: Task list for response to National assembly, Nigeria: SURE-P Annual Report, 2012.

[46]. T. Ogbebo, The Gains of SURE P (www.hotnigerianjobs.com, 2014).

[47]. T. Ogbebo, The Gains of SURE P (www.hotnigerianjobs.com, 2014). 